Check for updates

Cite this: RSC Adv., 2017, 7, 26625

Received 16th January 2017

Accepted 29th April 2017

DOI: $10.1039 / c 7 r a 00658 f$

rsc.li/rsc-advances

\section{Microwave-assisted synthesis of polypyridyl ruthenium(II) complexes as potential tumor- targeting inhibitors against the migration and invasion of Hela cells through G2/M phase arrest $\uparrow$}

\begin{abstract}
Jieqiong Cao, $\hbar^{\mathrm{a}}$ Qiong Wu, (D) $t^{\mathrm{b}}$ Wenjie Zheng, ${ }^{\text {abd }} \mathrm{Li} \mathrm{Li}^{\mathrm{c}}$ and Wenjie Mei (DD *c
A series of polypyridyl ruthenium(॥) complexes coordinated by phenanthroimidazole derivatives $\left[\mathrm{Ru}(\text { phen })_{2}(\mathrm{R})\right]\left(\mathrm{ClO}_{4}\right)_{2}$ (where $1 \mathrm{R}=\mathrm{IP}, 2 \mathrm{R}=\mathrm{PIP}, 3 \mathrm{R}=\mathrm{p}$-HPIP, $4 \mathrm{R}=\mathrm{p}$-OCH${ }_{3} \mathrm{PIP}$ ) was synthesized with an average yield of $>85 \%$ under microwave irradiation at $140{ }^{\circ} \mathrm{C}$ for $30 \mathrm{~min}$. The inhibitory effect of these complexes against various tumour cells were evaluated by MTT assay, and the results showed that these polypyridyl ruthenium(॥) complexes exhibited acceptable inhibition against different tumour cells, especially 4 , with an $\mathrm{IC}_{50}$ of $18.4 \mu \mathrm{M}$ for Hela cells. The results showed that 4 inhibited the growth of cervical cancer Hela cells by inducing G2/M phase arrest, which was followed by slight apoptosis. Further studies showed that 4 displayed better inhibition against the invasion and metastasis of Hela cells than NAMI-A. Studies on the in vivo distribution and metabolism indicated that 4 was rapidly distributed in the entire body, absorbed by the tumour tissue and had only a small accumulation of toxicity in the body. These results demonstrated that this type of ruthenium(॥) complex can block the growth of Hela cells and inhibit their migration and invasion through G2/M phase arrest, which suggests the complex could act as a potential tumour-targeting inhibitor in future clinical applications.
\end{abstract}

\section{Introduction}

Cervical cancer, especially metastatic cervical cancer with a high invasive potential and infinite proliferation, ${ }^{1-4}$ is the most common primary malignant tumour in women worldwide. $^{5-11}$ The worldwide incidence rate of cervical cancer has been on the rise in recent years, and its metastasis remains one of the main pathological conditions endangering human life worldwide. The treatment of cervical cancer faces one of the most challenging problems in clinical oncology in that there are few effective treatments to block the metastasis of cervical cancer cells. ${ }^{12-15}$

Ruthenium complexes have always been regarded as some of the most potential antitumour inhibitors owing to their decent antitumour activity ${ }^{16-20}$ and low toxicity. ${ }^{21-24} \mathrm{~A}$ number of Ru complexes have been designed and their anti-metastasis

${ }^{a}$ College of Pharmacy, Jinan University, Guangzhou, China. E-mail: tzhwj@jnu.edu.cn ${ }^{b}$ Integrated Chinese and Western Medicine Postdoctoral Research Station, Jinan University, Guangzhou, China

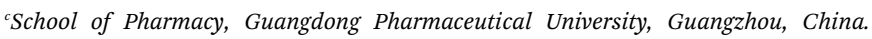
E-mail: wenjiemei@126.com

${ }^{d}$ Department of Chemistry, Jinan University, Guangzhou, China

$\dagger$ Electronic supplementary information (ESI) available. See DOI: 10.1039/c7ra00658f

\$ Equally contribution. activities against various tumours have been investigated extensively. ${ }^{25-27}$ For example, NAMI-A ${ }^{28,29}$ and KP1019 ${ }^{30}$ have entered phase II clinical studies as NAMI-A can selectively reduce tumour metastasis and inhibit tumour cell invasion in vitro and KP1019 can inhibit the migration and invasion of MDA-MB-231 breast cancer cells by reducing the release of the extracellular matrix (MMP-2/9). In addition, the Ru complex RM175 also exhibits tumour metastasis inhibition and reduces the invasion and metastasis by promoting cell-cell readhesion and by decreasing the release of metalloproteinases (MMPs). ${ }^{31}$ However, little attention has been paid to the inhibition of the migration and invasion of ruthenium polypyridyl complexes. ${ }^{32}$

In this study, a series of polypyridyl ruthenium(II) complexes, $\left[\mathrm{Ru}(\text { phen })_{2}(\mathrm{R})\right]\left(\mathrm{ClO}_{4}\right)_{2}$ (where $1 \mathrm{R}=\mathrm{IP}, 2 \mathrm{R}=\mathrm{PIP}, 3$ $\mathrm{R}=p$-HPIP, $4 \mathrm{R}=p$-OCH 3 PIP) were synthesized and demonstrated to inhibit the invasion and metastasis of Hela cells. The molecular mechanisms through which the ruthenium(II) complexes caused cancer cell death were also elucidated. This study demonstrated that polypyridyl ruthenium(II) complexes display great antitumour activity against cervical cancer cells and effectively inhibit the migration and invasion of Hela cells in vitro. Moreover, further study indicated that the polypyridyl ruthenium(II) complexes induced growth inhibition was mainly caused by cell cycle arrest at the G2/M phase. 


\section{Results and discussion}

\section{Synthesis of polypyridyl ruthenium(II) complexes}

Compared with the conventional heating method, microwaveassisted synthesis heating technology ${ }^{33-36}$ can significantly improve the yield of the compound and effectively reduce the reaction time. It was observed that the reaction system temperature could instantly reach $130{ }^{\circ} \mathrm{C}$ in less than 2 min under microwave irradiation, and the reaction condition stayed almost unchanged during the whole process (Fig. S1†). The average yields of 1, 2, 3 and 4 under microwave irradiation were greater than $80 \%$, which was far more higher than typically obtained under the conventional heating method (Table S1 $\dagger$ ). Through orthogonal tests, we obtained the optimized reaction conditions, including reaction temperature $\left(130{ }^{\circ} \mathrm{C}\right)$, reaction

Table 1 Cytotoxic effects of the Ru(I) complexes on human cancer cell lines

\begin{tabular}{lllll}
\hline & \multicolumn{2}{l}{$\mathrm{IC}_{50} / \mu \mathrm{M}$} & & \\
\cline { 2 - 4 } Comp. & Hela & Siha & Caski & $\log P$ \\
\hline $\mathbf{1}$ & 84.8 & $>100$ & 73.8 & -0.35 \\
$\mathbf{2}$ & 48.8 & $>100$ & 53.1 & 0.05 \\
$\mathbf{3}$ & 24.5 & 83.2 & 17.4 & -0.23 \\
$\mathbf{4}$ & 18.4 & 49.4 & 21.9 & -0.12 \\
NAMI-A & $>100$ & $>100$ & $>100$ & -2.57
\end{tabular}

time (30 $\mathrm{min})$ and the weight ratio of materials $(1: 1.5)$, with a high average yield of $92.38 \%$. These results indicated that microwave irradiation could decrease the time consumption and increase the yield.

\section{Biological activity}

The in vitro inhibitory activities of the polypyridyl ruthenium(II) complex against cervical cancer cells (Hela, Siha, Caski) were evaluated by MTT assay. As shown in Table 1, it was found that all of the four ruthenium(II) complexes exhibited moderate anti-proliferative activity against several cancer cells, and that this effect was dosage-dependent. It was seen that the inhibitory activity of these complexes against the growth of Hela cells followed the sequence $\mathbf{1}<\mathbf{2}<\mathbf{3}<\mathbf{4}$, indicating that the planarity of the main ligand and electrondonating groups in the main ligand play a key role in enhancing the inhibitory activity of these complexes. Compared with 1 and 2, with the introduction of a benzene ring at the end of the imidazole ring, 2 exhibited better antitumour activity. Moreover, the most active complex was $\mathbf{4}$ with a methoxy group at the para-position in the end benzene ring, which displayed a broad spectrum growth inhibition against several cancer cells, especially for Hela cells, with an $\mathrm{IC}_{50}$ value of $18.4 \mu \mathrm{M}$, compared to the biological activity with the other ruthenium(II) complexes, such as $\left[\left(\mathrm{Ru}(\text { phen })_{2}\right)_{2}(\text { tpphz })\right]^{4+}$, which had an $\mathrm{IC}_{50}$ value to Hela cells of $>200 \mu \mathrm{M},{ }^{37}$ and $\left[\left(\mathrm{C}_{6} \mathrm{H}_{6}\right) \mathrm{Ru}\left(p-\mathrm{NMe}_{2} \mathrm{PIP}\right) \mathrm{Cl}\right] \mathrm{Cl} \cdot 2 \mathrm{H}_{2} \mathrm{O}$, which had an $\mathrm{IC}_{50}$ value to Hela cells of $88.5 \mu \mathrm{M} .^{38}$ These results were
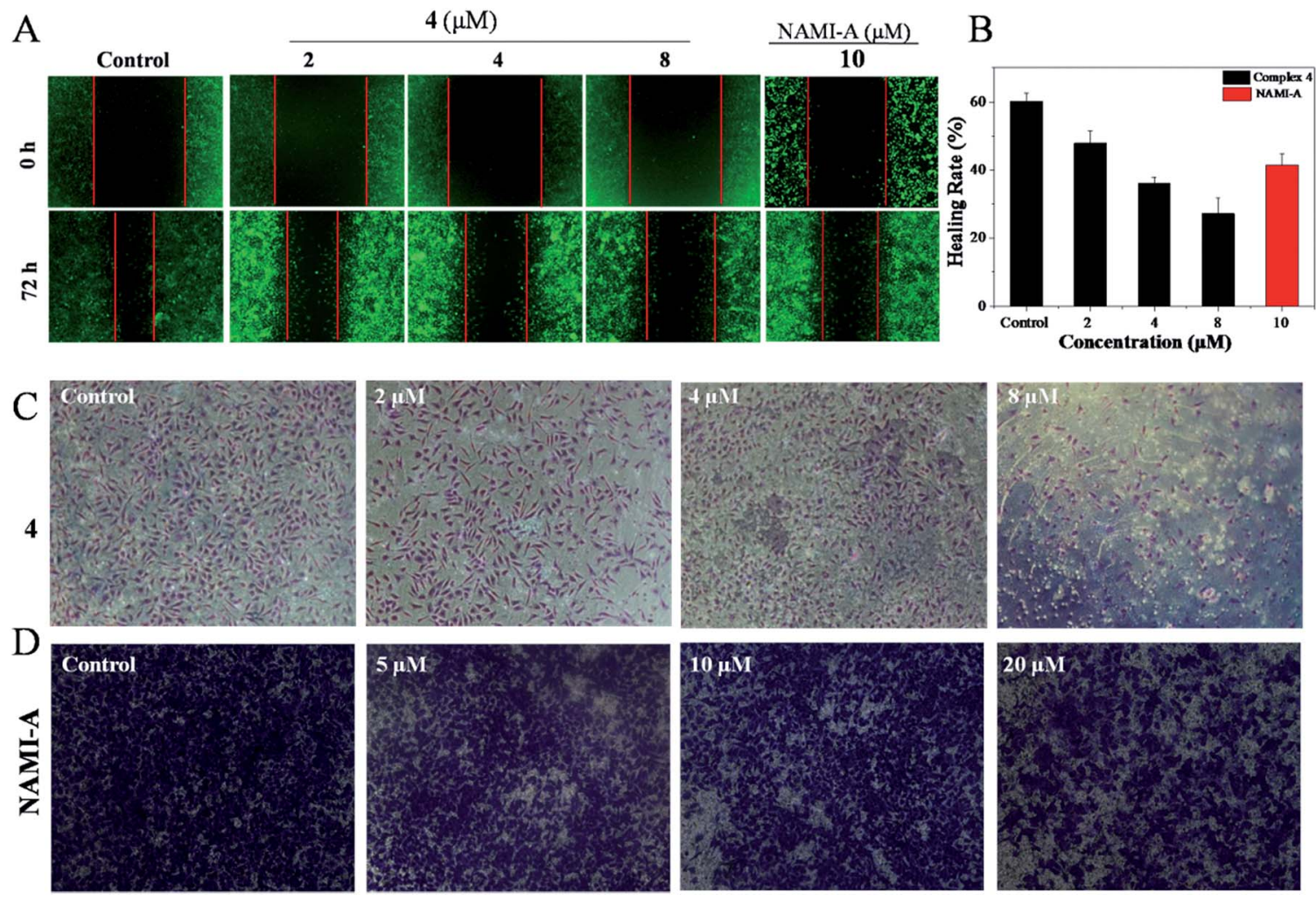

Fig. 1 (A) The wound healing assay of Hela cells after treatment with $4(0,2,4$ and $8 \mu M)$ and $[N A M I-A]=10 \mu M$. (B) The healing rate of Hela cells treated with 4 and NAMI-A. (C) The transwell assay of Hela cells after treatment with $4(0,2,4$ and $8 \mu \mathrm{M})$ and $(\mathrm{D})[\mathrm{NAMI}-\mathrm{A}]=(0,5,10$ and $20 \mu \mathrm{M})$. 
reasonable given that the introduction of a benzene ring and the presence of donor substituents can improve the antitumour activity.

Lipophilicity often exerts an effect on a compound's bioavailability and effectiveness. Thus, we investigated the octanol/water partition coefficients of these complexes by ultraviolet detection. The lipophilicity partition coefficients for $1,2,3,4$ and NAMI-A were approximately $-0.35,0.05,-0.23$, -0.12 and -2.57 , respectively. Therefore, we concluded that the molecular polarity changes with the size of the substituents as well as with their electron-donating power. ${ }^{25}$

\section{Inhibition of migration and invasion against Hela cells}

As is well known, metastasis is the major cause of death from cervical cancer, and is a process that includes migration and invasion. As shown in Fig. 1A, the inhibitory effect of 4 against the migration of Hela cells was evaluated by wound healing assays. ${ }^{39}$ It was found that Hela cells treated without 4 showed a decreasing distance of wound closure at $72 \mathrm{~h}$; however, an increasing distance of wound closure was observed with the further addition of 4 . For Hela cells treated with $4([\mathrm{Ru}]=2 \mu \mathrm{M})$, the healing rate of scratches was about $47.9 \%$, which was far lower than the healing rate for Hela cells treated without 4 (60\%). These results can be compared to Hela cells treated with NAMI-A $([\mathrm{Ru}]=10 \mu \mathrm{M})$ with a healing rate of $41.5 \%$. When the concentration of 4 was increased up to $8 \mu \mathrm{M}$, the scratches healing degree was significantly reduced to $27.2 \%$ (Fig. 1B). These data suggest that $\mathbf{4}$ can inhibit the migration of Hela cells effectively.

The transwell invasion assay is usually applied to observe the number of invasive tumour cells. In general, cells with high invasion rates can form invadopodia to release MMPs, which degrade the matrigel and migrate to the other side of the membrane. The more cells migrate to other membranes, the stronger the invasion of the cells. Compared with the control, the invasion of Hela cells was blocked with the increasing concentration of 4 . After being treated with $2 \mu \mathrm{M}$ of 4 , the number of Hela cells that degraded the matrigel decreased markedly. With the increase in $\mathbf{4}$, the invasion ability of Hela cells was clearly blocked as could be observed from the fact that few cells migrated to another membrane (Fig. 1C). Treatment with 4 even exhibited better inhibition of invasion at $8 \mu \mathrm{M}$ with the healing rate of $27.2 \%$ than NAMI-A with a healing rate of $41.5 \%,(5 \mu \mathrm{M})$ which is an anti-metastasis agent in vivo (Fig. 1D). These data revealed that the invasion abilities of Hela cells could be blocked by $\mathbf{4}$ significantly.

\section{In vivo distribution and metabolism}

Furthermore, tests on the in vivo distribution and metabolism of 4 were conducted on tumour-bearing nude mice. As shown in

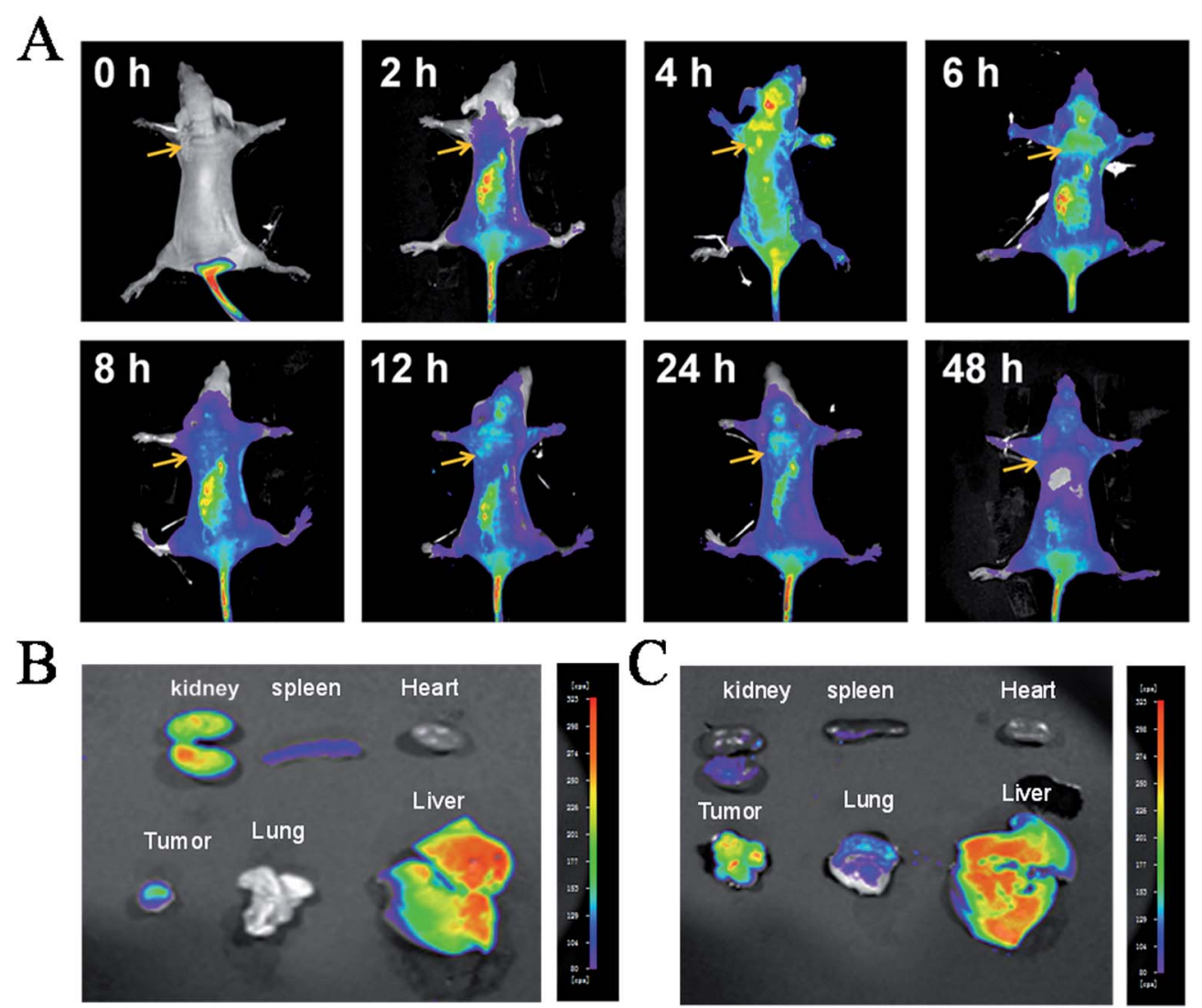

Fig. 2 In vivo distribution and metabolism of polypyridyl Ru(॥) 4. (A) The distribution and localization of $4\left(5 \mathrm{mg} \mathrm{kg}^{-1}\right)$ in vivo. Tissue distribution of 4 for $6 \mathrm{~h} \mathrm{(B)} \mathrm{and} 48 \mathrm{~h} \mathrm{(C).} \mathrm{(Excited} \mathrm{by} 475 \mathrm{~nm}$, emission at $600 \mathrm{~nm}$ ). 


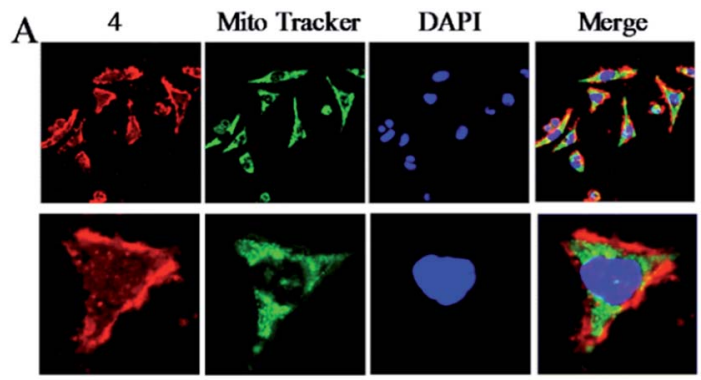

B

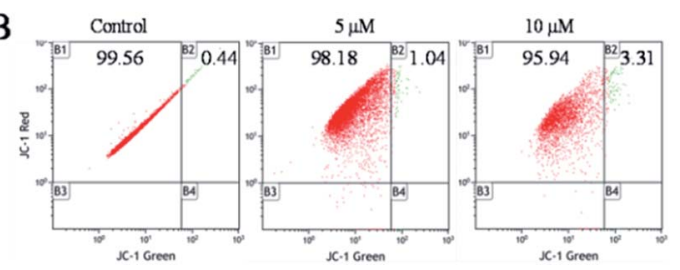

Fig. 3 (A) The distribution of 4 in Hela cells for 6 h, blue: DAPI (10 nM), green: Mito-Tracker $(10 \mathrm{nM})$, red: $4=5 \mu \mathrm{M}$. (B) Change in mitochondrial membrane potential of Hela cells incubated with $4(0,5$ and $10 \mu \mathrm{M})$ for $24 \mathrm{~h}$ as tested by flow cytometric analysis.

Fig. 2A, with the injection of $\mathbf{4}$ into the tail vein, the drug was quickly distributed in the whole body, even passing the bloodbrain barrier in the head, with the maximum concentration occurring at $6 \mathrm{~h}$. However, as time goes on, the complex is progressively metabolized out, with increasingly weaker fluorescence in the body, indicating that 4 can be metabolized normally and dropped out of the mouse body. Then at $48 \mathrm{~h}$, little fluorescence of the complex was observed, indicating that the complex was almost totally eliminated from the mice. Moreover, further studies showed that at 6 h, (Fig. 2B), 4 was mainly accumulated in the liver, kidney and tumour tissue together with a small distribution in the heart, lung and spleen. After $48 \mathrm{~h}$, the complexes still had a large amount of accumulation of tumour tissue in vivo, suggesting that $\mathbf{4}$ could enrich in tumour tissue, but also can be accumulated in the liver (Fig. 2C). The above results indicated that $\mathbf{4}$ was easily distributed in nude mice and enriched in the tumour tissue, and could then be majorly metabolized by the liver and excreted by the kidney.

\section{Cellular localization}

To clarify the underlying mechanism of $\mathbf{4}$ against the migration and invasion of Hela cells, the cellular localization was first studied. After the incubation of 4 for $6 \mathrm{~h}$, it was observed that 4 (red) was distributed in the whole cell, and enriched in the surface of the cell membrane, and there was a certain number of $\mathbf{4}$ also distributed in the nucleus (blue) and the mitochondria (green) (Fig. 3A). Further study showed that with increasing the concentration of $\mathbf{4}$, there was little influence on the mitochondrial membrane potential as observed by JC-1 tests (Fig. 3B). These results suggested that 4 was mainly distributed in the surface of the cell membrane, which induced the death of tumour cells through a nonmitochondria-mediated pathway. ${ }^{40}$
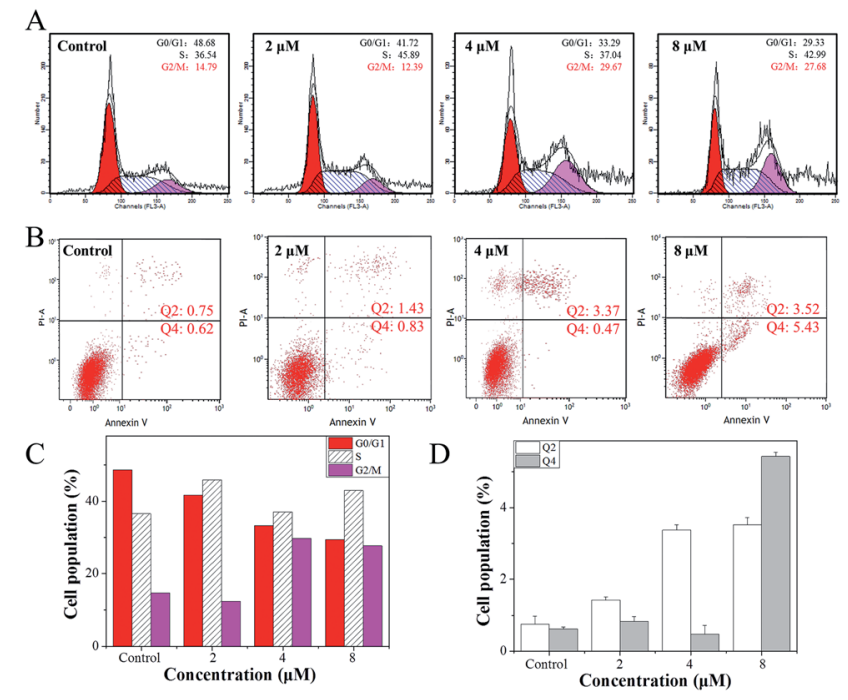

Fig. 4 (A) Cell cycle distribution of Hela cells incubated with 4 (0, 2, 4 and $8 \mu \mathrm{M})$ for $24 \mathrm{~h}$ tested by flow cytometric analysis. (B) Apoptosis of Hela cells induced by $4(0,2,4$ and $8 \mu \mathrm{M})$; (C) change in cell cycle distribution of Hela cells induced by $4(0,2,4$ and $8 \mu \mathrm{M})$. (D) Cells population of apoptosis of Hela cells induced by $4(0,2,4$ and $8 \mu \mathrm{M})$.

\section{Cell phase arrest induced by the $\mathrm{Ru}(\mathrm{II})$ complex}

The growth inhibition or death of cells is the result of apoptosis, cell cycle arrest or a combined action of both. ${ }^{41}$ Therefore, flow cytometry analysis was carried out to determine the action of 4 . According to the results, it was revealed that $\mathbf{4}$ induced growth inhibition was mainly caused by cell cycle arrest at the G2/M phase. After Hela cells were exposed to different concentrations of 4, a significant increase in the cell proportion in the G2/ $\mathrm{M}$ phase of Hela cells was observed (Fig. 4A). For instance, when the concentration of 4 reached $4 \mu \mathrm{M}$, the G2/M phase cells peak increased from $14.79 \%$ to $29.67 \%$, while there was a significant decrease in cell proportion in the G0/G1 phase, while the $\mathrm{S}$ phase proportion of cells showed no obvious change with different concentrations of $\mathbf{4}$.

Furthermore, a large number of studies in the literature $\mathbf{4 2 - 4 5}^{\mathbf{2}}$ have reported that small molecule drugs that induce $\mathrm{G} 2 / \mathrm{M}$ phase arrest could eventually induce tumour cell apoptosis. However, after Hela cells were treated with 4, little apoptosis was observed (Fig. 4B). With the addition of 4 , when the concentration reached $2 \mu \mathrm{M}$, the Hela cells early apoptosis rate was just 0.83 , while the late apoptosis rate was 1.43 , and even when the concentration of 4 was increased to $8 \mu \mathrm{M}$, the Hela cells early apoptosis rate was only 5.43 , while the late apoptosis rate was 3.52. These results indicate that 4 mainly inhibits the growth of Hela cells through G2/M phase arrest.

\section{Conclusions}

In conclusion, a series of ruthenium(II) complexes $\left[\mathrm{Ru}(\text { phen })_{2}(\mathrm{R})\right]\left(\mathrm{ClO}_{4}\right)_{2}$ (where $1 \mathrm{R}=\mathrm{IP}, 2 \mathrm{R}=\mathrm{PIP}, 3 \mathrm{R}=p$-HPIP, 4 $\left.\mathrm{R}=p-\mathrm{OCH}_{3} \mathrm{PIP}\right)$ were synthesized with high efficiency and high yield under microwave irradiation. It was demonstrated that all of these complexes, especially 4, exhibited promising inhibitory 
effect against Hela cells. Further studies showed that 4 could also inhibit the migration and invasion of Hela cells effectively. Moreover, in vivo studies showed that $\mathbf{4}$ could be enriched in tumour tissue. It was also confirmed that $\mathbf{4}$ could inhibit the growth of Hela cells through G2/M phase arrest. Therefore, these complexes may be developed as potential targeting inhibitors against the migration and invasion of Hela cells through inducing G2/M phase arrest.

\section{Experimental}

\section{Reagents and materials}

All the reagents were purchased from commercial suppliers without further purification. Solvents were dried and purified by conventional methods prior to use. Ruthenium chloride hydrate was obtained from Mitsuwa Chemicals. 1,10-Phenanthroline, formaldehyde, benzaldehyde, 4-methoxy benzaldehyde and 4hydroxybenzaldehyde were purchased from Aladdin. Ammonium acetate, ammonia, sodium perchlorate, sulfuric acid, nitric acid, potassium bromide, anhydrous ethanol and anhydrous methanol were purchased from Guangzhou Chemical Reagent factory.

\section{Instruments}

The compound was synthesized using an Anton Paar Monowave 300 microwave reactor. The ${ }^{1} \mathrm{H}$ NMR and ${ }^{13} \mathrm{C}$ NMR spectra were recorded in $d^{6}$-DMSO on a Bruker DRX2500 spectrometer operating at room temperature. Cell apoptosis was measured using a flow cytometer (Beckman Coulter, Miami, FL, USA).

\section{Synthesis and characterization}

Synthesis of $\left[\mathrm{Ru}(\mathrm{phen})_{2} \mathbf{C l}_{2}\right] \cdot 2 \mathbf{H}_{2} \mathrm{O}$. 1,10-Phenanthroline (2.67 g, $15 \mathrm{mmol})$, lithium chloride (1.91 g, $45 \mathrm{mmol}$ ) and ruthenium trichloride $(1.96 \mathrm{~g}, 7.5 \mathrm{mmol})$ were added to a $50 \mathrm{~mL}$ three-neck flask, then $15 \mathrm{~mL}$ of DMF and a mixed solution of distilled water was added and then the mixture was stirred for $8 \mathrm{~h}$ at $140{ }^{\circ} \mathrm{C}$ under nitrogen protection. After the reaction, to the cooled reaction mixture was added acetone $(50 \mathrm{~mL})$. The flask was placed in $4{ }^{\circ} \mathrm{C}$ environment overnight. The next day, the filter cake was collected and washed with water and acetone several times, and after drying, black-purple crystals were obtained.
Synthesis of $\left[\mathbf{R u}(\text { phen })_{2}(\mathrm{IP})\right]\left(\mathrm{ClO}_{\mathbf{4}}\right)_{\mathbf{2}}$ (1). $\left[\mathrm{Ru}(\text { phen })_{2}(\mathrm{IP})\right]\left(\mathrm{ClO}_{4}\right)_{2}$ was prepared by a microwave-assisted synthesis technology (Scheme 1). In general, a mixture of $\left[\mathrm{Ru}(\text { phen })_{2} \mathrm{Cl}_{2}\right] \cdot 2 \mathrm{H}_{2} \mathrm{O}(54 \mathrm{mg}$, $0.1 \mathrm{mmol}$ ) and IP (33 mg, $0.15 \mathrm{mmol}$ ) was added to ethylene glycol $(20 \mathrm{~mL})$ under nitrogen for $10 \mathrm{~min}$, then irradiated by microwave for $30 \mathrm{~min}$ at $140{ }^{\circ} \mathrm{C}$. The cooled reaction mixture was diluted with water, followed by vacuum filtration to remove the insoluble precipitate to obtain a reddish brown solution. An appropriate amount of sodium perchlorate was added to the filtrate to obtain lots of orange-red suspended solids. The orangered suspended solid was collected and washed with water and ether several times, respectively. Drying obtained a reddish brown solid, which was finally purified by $\mathrm{Al}_{2} \mathrm{O}_{3}$ column chromatography. ESI-MS: (in $\left.\mathrm{CH}_{3} \mathrm{CN}, m / z\right): 341.0\left(\left[\mathrm{M}-2 \mathrm{ClO}_{4}\right]^{2+}\right.$, cal: 341.06). ${ }^{1} \mathrm{H}$ NMR (500 MHz, $d^{6}$-DMSO) $\delta 8.99(\mathrm{~d}, J=8.2 \mathrm{~Hz}, 2 \mathrm{H})$, $8.78(\mathrm{~d}, J=3 \mathrm{~Hz}, 4 \mathrm{H}), 8.75(\mathrm{~s}, 1 \mathrm{H}), 8.40(\mathrm{~s}, 4 \mathrm{H}), 8.12(\mathrm{dd}, J=5.2$, $0.9 \mathrm{~Hz}, 2 \mathrm{H}), 8.09$ (dd, $J=5.2,0.9 \mathrm{~Hz}, 2 \mathrm{H}), 8.01(\mathrm{~d}, J=2 \mathrm{~Hz}, 2 \mathrm{H})$, 7.84-7.72 (m, 7H). ${ }^{13} \mathrm{C}$ NMR (126 MHz, d $d^{6}$-DMSO) $\delta 153.30(\mathrm{~s})$, 153.13 (s), 150.77 (s), 147.66 (d, $J=9.4 \mathrm{~Hz}), 145.94(\mathrm{~s}), 143.53(\mathrm{~s})$, 137.27 (d, $J=5.1 \mathrm{~Hz}), 130.92$ (s), 130.74 (s), 128.53 (s), 127.20$126.34(\mathrm{~m})$.

Synthesis of $\left[\mathrm{Ru}(\text { phen })_{2}(\mathrm{PIP})\right]\left(\mathrm{ClO}_{4}\right)_{2} \quad$ (2). $\left[\mathrm{Ru}(\text { phen })_{2} \mathrm{Cl}_{2}\right]$. $2 \mathrm{H}_{2} \mathrm{O}$ (54 mg, $0.1 \mathrm{mmol}$ ) and PIP (44.4 mg, $0.15 \mathrm{mmol}$ ) were reacted together using the same method as that used to prepare $\left[\mathrm{Ru}(\text { phen })_{2}(\mathrm{IP})\right]\left(\mathrm{ClO}_{4}\right)_{2}$, as described before, to obtain red solid $\left[\mathrm{Ru}(\text { phen })_{2}\right.$ (PIP) $]\left(\mathrm{ClO}_{4}\right)_{2}$. ESI-MS: (in $\left.\mathrm{CH}_{3} \mathrm{CN}, \mathrm{m} / \mathrm{z}\right): 379.0([\mathrm{M}-$ 2 $\left.\mathrm{ClO}_{4}\right]^{2+}$, cal: 379.08$) .{ }^{1} \mathrm{H}$ NMR (500 MHz, $d^{6}$-DMSO) $\delta 9.08(\mathrm{~d}, J$ $=8.3 \mathrm{~Hz}, 2 \mathrm{H}), 8.79(\mathrm{~d}, J=8.3 \mathrm{~Hz}, 4 \mathrm{H}), 8.41(\mathrm{~s}, 4 \mathrm{H}), 8.34(\mathrm{~d}, J=$ $7.4 \mathrm{~Hz}, 2 \mathrm{H}), 8.15(\mathrm{~d}, J=5.3 \mathrm{~Hz}, 2 \mathrm{H}), 8.10(\mathrm{~d}, J=5.2 \mathrm{~Hz}, 2 \mathrm{H}), 8.02$ $(\mathrm{d}, J=5.2 \mathrm{~Hz}, 2 \mathrm{H}), 7.80(\mathrm{ddd}, J=13.4,8.3,5.3 \mathrm{~Hz}, 6 \mathrm{H}), 7.66(\mathrm{t}, J$ $=7.6 \mathrm{~Hz}, 2 \mathrm{H}), 7.59$ (t, $J=7.3 \mathrm{~Hz}, 2 \mathrm{H}) .{ }^{13} \mathrm{C} \mathrm{NMR}\left(126 \mathrm{MHz}, d^{6}-\right.$ DMSO) $\delta 151.57$ (d, $J=18.9 \mathrm{~Hz}), 149.02(\mathrm{~s}), 146.06$ (d, $J=11.2$ Hz), 144.22 (s), 135.66 (s), 129.57-128.71 (m), 128.05 (s), 126.92 (s), 125.19 (dd, $J=32.1,26.3 \mathrm{~Hz}$ ).

Synthesis of $\left[\mathbf{R u}(\text { phen })_{2}(\boldsymbol{p}\right.$-HPIP $\left.)\right]\left(\mathrm{ClO}_{4}\right)_{2}$ (3). $\left[\mathrm{Ru}(\text { phen })_{2} \mathrm{Cl}_{2}\right]$. $2 \mathrm{H}_{2} \mathrm{O}$ (54 mg, $0.1 \mathrm{mmol}$ ) and $p$-HPIP (46.8 mg, $0.15 \mathrm{mmol}$ ) were reacted together using the same method as that used to prepare $\left[\mathrm{Ru}(\text { phen })_{2}(\mathrm{IP})\right]\left(\mathrm{ClO}_{4}\right)_{2}$, as described before, to obtain red solid $\left[\mathrm{Ru}(\text { phen })_{2}(p\right.$-HPIP $\left.)\right]\left(\mathrm{ClO}_{4}\right)_{2}$. ESI-MS: (in $\left.\mathrm{CH}_{3} \mathrm{CN}, \mathrm{m} / z\right)$ : $773.3([\mathrm{M}$ $\left.-2 \mathrm{ClO}_{4}{ }^{-}-\mathrm{H}^{+}\right]^{+}$, cal: 773.14); $387.3\left(\left[\mathrm{M}-2 \mathrm{ClO}_{4}{ }^{-}\right]^{2+}\right.$, cal: 387.07). ${ }^{1} \mathrm{H}$ NMR (400 MHz, $d^{6}$-DMSO) $\delta 9.08$ (d, $\left.J=8.2 \mathrm{~Hz}, 2 \mathrm{H}\right)$, $8.78(\mathrm{dd}, J=8.3,1.1 \mathrm{~Hz}, 4 \mathrm{H}), 8.40(\mathrm{~s}, 4 \mathrm{H}), 8.22-8.16(\mathrm{~m}, 2 \mathrm{H})$, $8.14(\mathrm{dd}, J=5.3,1.1 \mathrm{~Hz}, 2 \mathrm{H}), 8.09$ (dd, $J=5.2,1.2 \mathrm{~Hz}, 2 \mathrm{H}), 7.99$

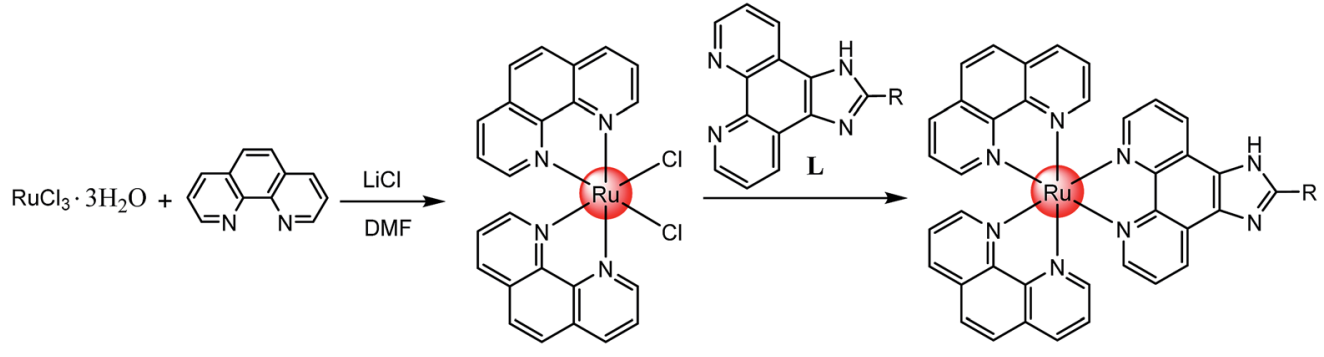

$1 \mathrm{R}=\mathrm{H} \quad 2 \mathrm{R}=$ Benzene $\quad 3 \mathrm{R}=4-\mathrm{OH}-$ Benzene $\quad 4 \mathrm{R}=4-\mathrm{OCH}_{3}-\mathrm{Benzene}$

Scheme 1 Synthesis route of the polypyridyl ruthenium(॥) complexes. 
(dt, $J=15.7,7.8 \mathrm{~Hz}, 2 \mathrm{H}), 7.87-7.61(\mathrm{~m}, 6 \mathrm{H}), 7.08-6.91(\mathrm{~m}, 2 \mathrm{H})$. ${ }^{13} \mathrm{C}$ NMR (126 MHz, $d^{6}$-DMSO) $\delta 154.32(\mathrm{~s}), 154.16(\mathrm{~s}), 153.33(\mathrm{~s})$, 152.70 (s), 150.96 (s), 150.79 (s), 147.13 (s), 142.22 (s), 140.83 (s), 140.67 (s), 140.46 (s), 137.01 (s), 135.60 (s), 133.24 (s), 131.21 (s), 130.52 (s), 129.82 (d, J=11.2 Hz), 128.09 (s), 127.65 (s), 126.33 (d, $J=14.4 \mathrm{~Hz}$ ), 125.92 (s).

Synthesis of $\left[\mathrm{Ru}(\text { phen })_{2}(\right.$ p-MOPIP $\left.)\right]\left(\mathrm{ClO}_{4}\right)_{2}$ (4). $\left[\mathrm{Ru}(\text { phen })_{2^{-}}\right.$ $\left.\mathrm{Cl}_{2}\right] \cdot 2 \mathrm{H}_{2} \mathrm{O}$ (54 mg, $0.1 \mathrm{mmol}$ ) and $p$-MOPIP (48.9 mg, $0.15 \mathrm{mmol}$ ) were reacted together using the same method as that used to prepare $\left[\mathrm{Ru}(\text { phen })_{2}(\mathrm{IP})\right]\left(\mathrm{ClO}_{4}\right)_{2}$, as described before, to obtain red solid $\left[\mathrm{Ru}(\text { phen })_{2}(p\right.$-MOPIP $\left.)\right]\left(\mathrm{ClO}_{4}\right)_{2}$. ESI-MS: (in $\left.\mathrm{CH}_{3} \mathrm{CN}, \mathrm{m} / z\right)$ : 787.2 ([M $\left.-2 \mathrm{ClO}_{4}{ }^{-}-\mathrm{H}^{+}\right]^{+}$, cal: 787.16); $394.3\left(\left[\mathrm{M}-2 \mathrm{ClO}_{4}{ }^{-}\right]^{2+}\right.$, cal: 394.08). ${ }^{1} \mathrm{H}$ NMR (500 MHz, $d^{6}$-DMSO) $\delta 8.97$ (d, $J=8.3 \mathrm{~Hz}$, $1 \mathrm{H}), 8.80-8.69(\mathrm{~m}, 2 \mathrm{H}), 8.55(\mathrm{~d}, J=8.9 \mathrm{~Hz}, 1 \mathrm{H}), 8.44-8.26(\mathrm{~m}, 3 \mathrm{H})$, $8.13(\mathrm{dt}, J=7.1,3.5 \mathrm{~Hz}, 1 \mathrm{H}), 8.10(\mathrm{dd}, J=5.2,1.1 \mathrm{~Hz}, 1 \mathrm{H}), 7.88(\mathrm{~d}$, $J=4.8 \mathrm{~Hz}, 1 \mathrm{H}), 7.77(\mathrm{dt}, J=8.3,4.9 \mathrm{~Hz}, 2 \mathrm{H}), 7.69(\mathrm{dd}, J=8.2$, $5.3 \mathrm{~Hz}, 1 \mathrm{H}) .{ }^{13} \mathrm{C} \mathrm{NMR}\left(126 \mathrm{MHz}, d^{6}\right.$-DMSO) $\delta 153.30(\mathrm{~s}), 148.00(\mathrm{~s})$, 147.90 (s), 145.68 (s), 137.36 (s), 131.13 (s), 130.80 (s), 128.75 (s), 127.52 (s), 126.99 (s), 126.23 (s), 124.89 (s).

\section{MTT assay}

All the complexes were dissolved in DMSO with stock solution at $1 \mathrm{mM}$, and the cell viability was determined by measuring the ability of the cells to transform MTT into a purple formazan dye. Cells were seeded in 96-well tissue culture plates for $24 \mathrm{~h}$, and then the cells were incubated with different concentrations of the complex for $72 \mathrm{~h}$. After incubation, $20 \mathrm{~mL}$ per well of MTT solution ( $5 \mathrm{mg} \mathrm{mL}^{-1}$ phosphate buffered saline) was added and incubated for $5 \mathrm{~h}$. The colour intensity of the formazan solution, which reflects the cell growth conditions, was measured at $570 \mathrm{~nm}$ using a microplate spectrophotometer (SpectroAmaxt 250).

\section{Amphiphilicity measurements}

Octanol and distilled water (volume ratio $=1: 1$ ) were thoroughly mixed in an oscillator for $24 \mathrm{~h}$, then separated into a twophase solution. The test compound was added dropwise to the aqueous and octanol phases to give a $20 \mathrm{mM}$ solution with mixing. After separation, the final concentration of the water phase was denoted as $C_{\mathrm{w}}$ and the concentration of the octanol phase was denoted as $C_{\mathrm{o}}$. Both $C_{\mathrm{o}}$ and $C_{\mathrm{w}}$ were tested by ultraviolet-visible (UV-vis) spectrophotometry, and the partition coefficient $\left(P_{\mathrm{o} / \mathrm{w}}\right)$ for the complex was calculated according to the equation: $P_{\mathrm{o} / \mathrm{w}}=A_{\mathrm{o}} / A_{\mathrm{w}}$.

\section{Wound healing assay}

Cells were seeded in a 6-well tissue culture plate marked on the back $\left(1 \times 10^{5}\right.$ cells per well $)$ until the monolayer cells spread to more than $80 \%$ of the bottom of the culture plate. A line was scratched orthogonally using a tip $(200 \mathrm{~mL})$ to mark the plate. The cells were then incubated with the tested compounds at different concentrations $(0,2,4,8 \mu \mathrm{M})$ for $48 \mathrm{~h}$. Migrating cells were imaged in the same visual field every $12 \mathrm{~h}$ for three days. The healing rate were calculated according to the formula $1-$ $\left[D_{48}\right] /\left[D_{0}\right],\left[D_{48}\right]=$ wound distance at 48 th hour, $\left[D_{0}\right]=$ wound distance at 0th hour.

\section{Transwell assay}

Up to $50 \mathrm{~mL}$ of Matrigel was added into the top chamber of the 24-well transwell on ice, and the plate was then incubated at $37{ }^{\circ} \mathrm{C}$ and with $5 \% \mathrm{CO}_{2}$ for $30 \mathrm{~min}$. Afterward, the cells were placed in the top chamber with serum-free media having different concentrations $(0,2,4,8 \mu \mathrm{M})$, while the bottom chamber was added with DMEM containing 10\% FBS and incubated for $24 \mathrm{~h}$. Cell invasion was imaged using a fluorescence microscope.

\section{In vivo biodistribution and target studies}

BALB/c nude mice were provided by Guangdong Medical Laboratory Animal Center. The injection was prepared $(50 \mathrm{~mL})$ using physiological saline, DMF and twain (88:10:2), with $2.5 \mathrm{mg}$ of the drug dissolved in $5 \mathrm{~mL}$ injection. Each rat was injected $200 \mu \mathrm{L}$, and every $2 \mathrm{~h}(2-48 \mathrm{~h})$ an in vivo imaging system (Bruker) was used to detect drug absorption and distribution in the nude mice tissues and organs. When the drug was observed with a large distribution in the tumour tissue site, the heart, liver, spleen, lung and kidney were taken out and photographed. The relevant ethical protocols used for the in vivo study for the BALB/c nude rat were followed according to the relevant laws. The animals were maintained in accordance with the Guide for the Care and Use of Laboratory Animals issued by the National Institutes of Health, and approved by the Laboratory Animal Ethics Committee of Jinan University.

\section{Cellular localization}

Cells in incomplete growth medium at $2 \times 10^{5}$ cells per $\mathrm{mL}$ were incubated with the tested complex at different concentrations $(0,2,4,8 \mu \mathrm{M})$ for $6 \mathrm{~h}$, then, the cells were stained with DAPI and Mitotracker green FM for another $10 \mathrm{~min}$. Next, they were removed from the medium and washed with PBS 3 times, and finally luminescence imaging was carried out by confocal microscopy.

\section{Flow cytometry analysis of the mitochondrial membrane potential}

Treated tumour cells were trypsinized, with $10 \mathrm{ug} \mathrm{mL} \mathrm{m}^{-1}$ of $0.5 \mathrm{~g}$ $\mathrm{mL}^{-1} \mathrm{JC}-1 \mathrm{~mL}$ PBS buffer solution $(0.5 \mathrm{~mL})$ suspension and then incubated at $37{ }^{\circ} \mathrm{C}$ for $10 \mathrm{~min}$, immediately followed by centrifuging to remove the suspended solids. Then, the cell suspension in PBS buffer solution was subjected to flow cytometry analysis. Green fluorescence intensity produced by the JC-1 monomer showed cell membrane potential losses $\Delta \Psi$.

\section{Flow cytometry analysis of cycle arrest}

The cell cycle distribution was analyzed by flow cytometry as previously reported. ${ }^{46}$ Treated or untreated cells were trypsinized, washed with PBS, and fixed with $70 \%$ ethanol overnight at $4{ }^{\circ} \mathrm{C}$. Fixed cells were washed with PBS and stained with propidium iodide (PI) $\left(1.21 \mathrm{mg} \mathrm{mL}^{-1}\right.$ Tris, $700 \mathrm{U} \mathrm{mL}^{-1}$ RNase, $50.1 \mathrm{mg} \mathrm{mL}{ }^{-1} \mathrm{PI}, \mathrm{pH}=8.0$ ) for $15 \mathrm{~min}$ in the dark. After staining the cells, they were analyzed using the Epics XL-MCL flow cytometry instrument (Beckman Coulter, Miami, FL, 
USA). Cell cycle distribution was analyzed using the MultiCycle software (Phoenix Flow Systems, San Diego, CA, USA). Apoptotic cells with hypodiploid DNA content were measured by quantifying the sub-G1 peak in the cell cycle pattern.

\section{Acknowledgements}

This work was supported by the National Nature Science Foundation of China (81572926), the Provincial Major Scientific Research Projects in Universities of Guangdong Province (2014KZDXM053), the Science and Technology Project of Guangdong Province (2014A020212312), Natural Science Fund of Guangdong (408182136045), Guangdong Medical Scientific Research Fund (A2015550), the Guangzhou City Science and Technology Plan (2013J4100072), the Science and Technology Projects of Yuexiu District (2014-WS-039) and the Joint Natural Sciences Fund of the Department of Science and Technology and the First Affiliated Hospital of Guangdong Pharmaceutical University (GYFYLH201309).

\section{Notes and references}

1 G. Ronco, J. Dillner, K. M. Elfström, S. Tunesi, P. J. Snijders, M. Arbyn, H. Kitchener, N. Segnan, C. Gilham and P. GiorgiRossi, Lancet, 2014, 383, 524-532.

2 J. Ferlay, H. R. Shin, F. Bray, D. Forman, C. Mathers and D. M. Parkin, Int. J. Cancer, 2010, 127, 2893-2917.

3 A. Serranoolvera, L. Cetina, J. Coronel and A. Dueñasgonzález, Expert Opin. Emerging Drugs, 2015, 20, 1-18.

4 D. G. Allen, R. S. Planner, P. T. Tang, J. P. Scurry and T. Weerasiri, Best Pract. Res. Clin. Obstet. Gynaecol., 2016, 33, 228.

5 S. E. Waggoner, Lancet, 2003, 361, 2217-2225.

6 F. X. Bosch, J. Natl. Cancer Inst., 1995, 87, 796-802.

7 R. Das, K. Bhattacharya, S. K. Samanta, B. C. Pal and C. Mandal, Cancer Lett., 2014, 351, 81-90.

8 D. M. Parkin, F. Bray, J. Ferlay and P. Pisani, Ca-Cancer J. Clin., 2005, 55, 74-108.

9 B. Li, Ca-Cancer J. Clin., 2011, 61, 33-64.

10 A. Jemal, F. Bray, M. M. Center, J. Ferlay, E. Ward and D. Forman, Ca-Cancer J. Clin., 2011, 61, 69-90.

11 R. Sankaranarayanan, A. M. Budukh and R. Rajkumar, Bull. World Health Organ., 2015, 79, 954-962.

12 K. S. Tewari, M. W. Sill, H. J. L. Iii, R. T. Penson, H. Huang, L. M. Ramondetta, L. M. Landrum, A. Oaknin, T. J. Reid and M. M. Leitao, N. Engl. J. Med., 2014, 370, 734-743.

13 Y. Dang, X. Yuan, R. Tian, L. I. Dongguang and W. Liu, Exp. Ther. Med., 2015, 9, 1470-1476.

14 R. N. Eskander and K. S. Tewari, Clin. Ther., 2015, 37, 20-38.

15 J. Manzomerino, A. Contrerasparedes, E. Vázquezulloa, L. Rochazavaleta, A. M. Fuentesgonzalez and M. Lizano, Arch. Med. Res., 2014, 45, 525-539.

16 L. Zeng, Y. Chen, J. Liu, H. Huang, R. Guan, L. Ji and C. Hui, Sci. Rep., 2016, 6, 19449.

17 Y. Chen, R. Guan, C. Zhang, J. Huang, L. Ji and H. Chao, Coord. Chem. Rev., 2016, 310, 16-40.
18 J. Liu, Y. Chen, G. Li, P. Zhang, C. Jin, L. Zeng, L. Ji and H. Chao, Biomaterials, 2015, 56, 140-153.

19 L. Xu, X. Chen, J. Wu, J. Wang, L. Ji and H. Chao, Chem.-Eur. J., 2015, 21, 4008-4020.

20 H. Huang, P. Zhang, H. Chen, L. Ji and H. Chao, Chemistry, 2015, 21, 715-725.

21 R. Pettinari, C. Pettinari, F. Marchetti, B. W. Skelton, A. H. White, L. Bonfili, M. Cuccioloni, M. Mozzicafreddo, V. Cecarini and M. Angeletti, J. Med. Chem., 2014, 57, 4532-4542.

22 C. Zheng, Y. Liu, L. Ying, X. Qin, Y. Zhou and L. Jie, J. Inorg. Biochem., 2016, 156, 122-132.

23 G. Sava, S. Zorzet, L. Perissin, G. Mestroni, G. Zassinovich and A. Bontempi, Inorg. Chim. Acta, 1987, 137, 69-71.

24 A. Weiss, R. H. Berndsen, M. Dubois, C. Müller, R. Schibli, A. W. Griffioen, P. J. Dyson and P. Nowak-Sliwinska, Chem. Sci., 2014, 5, 4742-4748.

25 Q. Wu, K. Zheng, S. Liao, Y. Ding, Y. Li and W. Mei, Organometallics, 2016, 35, 317-326.

26 Q. Wu, J. He, W. Mei, Z. Zhang, X. Wu and F. Sun, Metallomics, 2014, 6, 2204-2212.

27 C. Fan, Q. Wu, T. Chen, Y. Zhang, W. Zheng, Q. Wang and W. Mei, Med. Chem. Commun., 2014, 5, 597-602.

28 A. Bergamo, B. Gava, E. Alessio, G. Mestroni, B. Serli, M. Cocchietto, S. Zorzet and G. Sava, Int. J. Oncol., 2002, 21, 1331-1338.

29 M. Liu, Z. J. Lim, Y. Y. Gwee, A. L. Dr and P. A. L. Prof, Angew. Chem., 2010, 122, 1705-1708.

30 A. Bergamo, A. Masi, M. A. Jakupec, B. K. Keppler and G. Sava, Met.-Based Drugs, 2009, 2009, 681270.

31 A. Bergamo, A. Masi, A. Peacock, A. Habtemariam, P. Sadler and G. Sava, J. Inorg. Biochem., 2010, 104, 79-86.

32 A. Bergamo, A. Masi, A. F. Peacock, A. Habtemariam, P. J. Sadler and G. Sava, J. Inorg. Biochem., 2010, 104, 79-86.

33 F. A. Beckford, S. Michael, G. Leblanc, J. Thessing, L. C. Lewisalleyne, A. A. Holder, L. Li and N. P. Seeram, Dalton Trans., 2009, 48, 10757-10764.

34 H. Zhu, X. Wang, Y. Li, Z. Wang, F. Yang and X. Yang, Chem. Commun., 2009, 103, 887-896.

35 Q. Wu, J. Wu, W. J. Mei, Q. Wang, Z. Zhang, X. H. Wu, F. Y. Sun, W. L. Wu, Y. H. Chen and X. Y. Hu, Aust. J. Chem., 2013, 66, 1422-1427.

36 S. H. Jhung, J. H. Lee, J. W. Yoon, C. Seree, G. Ferey and J. S. Chang, Adv. Mater., 2007, 19, 121-124.

37 M. R. Gill, D. Cecchin, M. G. Walker, et al., Chem. Sci., 2013, 12, 4512-4519.

38 Q. Wu, C. Fan, T. Chen, C. Liu, W. Mei, S. Chen, B. Wang, Y. Chen and W. Zheng, Eur. J. Med. Chem., 2013, 63, 57-63. 39 D. E. F. Van, L. A. Amos and J. Löwe, Nature, 2001, 413, 3944.

40 F. Marques, L. Cortereal, A. P. D. M. Alves, I. Alho, T. S. Morais, A. I. Tomaz, M. H. Garcia and M. P. Bicho, Microsc. Microanal., 2013, 19, 9-10.

41 H. Ling, M. Fabbri and G. A. Calin, Nat. Rev. Drug Discovery, 2013, 12, 847-865.

42 M. Taron, C. Plasencia, A. Abad and C. Martin, Invest. New Drugs, 2000, 18, 139-148. 
43 E. Shtivelman, J. Sussman and D. Stokoe, Curr. Biol., 2002, 12, 919-924.

44 Y. Niu, Z. Wang, H. Huang, S. Zhong, W. Cai, Y. Xie and G. Shi, Cancer Lett., 2014, 347, 88-97.
45 N. Y. Tang, Y. T. Huang, C. S. Yu, Y. C. Ko, S. H. Wu, B. C. Ji, J. S. Yang, J. L. Yang, T. C. Hsia and Y. Y. Chen, Anticancer Res., 2011, 31, 1691-1702.

46 X. Wei, D. A. Sipkins, C. M. Pitsillides, J. Novak, I. Georgakoudi and C. P. Lin, Mol. Imaging, 2015, 4, 415-416. 